Academic Platform Journal of Engineering and Science

\title{
The Effect of Aerophine 3418A Collector Dosage on Niğde (Ulukışla-Madenköy) Complex Pb-Zn Sulphide Ore Flotation
}

\author{
${ }^{* 1}$ Tevfik Agacayak, ${ }^{2}$ Nur Benan Yilmaz \\ ${ }^{1}$ Konya Technical University, Faculty of Engineering and Natural Sciences, Mining Engineering, Campus-Konya, \\ tagacayak@ktun.edu.tr/tevfik@ selcuk.edu.tr, \\ ${ }^{2}$ Gümüştaş Mining and Trade Co., Tepeköy Mineral Processing, Research and Development Laboratory, Ulukışla-Niğde, \\ nury@gumustasmaden.com.tr,
}

Research Paper

Arrival Date: 22.08.2020

Accepted Date: 16.04.2021

\begin{abstract}
In this study, grinding + flotation experiments were performed on the sample of complex $\mathrm{Pb}-\mathrm{Zn}$ sulphide ore taken from Niğde (Ulukışla-Madenköy) region in Turkey. According to the mineralogical analysis of the ore sample used in experimental studies, it was determined that the ore composition contains calcite, quartz, pyrite, chalcopyrite, hematite, goethite, limonite, gypsum, galena, sphalerite, jarosite, arsenopyrite and marcasite minerals. In addition, Au and Ag grains were found to be inclusions in hematite, goethite and jarosite minerals. The experiments were carried out at a solid ratio of $30 \%$, a flow rate of $10 \mathrm{~L} / \mathrm{min}$, a stirring rate of $1250 \mathrm{rpm}$ and $\mathrm{pH}=9$. In flotation tests, lime is used as the $\mathrm{pH}$ regulator, zinc sulphate, sodium silicate as the depressant, sodium isobutyl dithiophosphine as the collector and methyl isobutyl carbinol as the frother. In the flotation studies, the effect of Aerophine 3418A collector dosage on flotation was investigated. As a result, a lead concentrate of $55.13 \% \mathrm{~Pb}$ was obtained and it was found that this concentrate contained $2489 \mathrm{ppm}$ of Ag. The amount of Aerophine 3418A collector was determined as $10 \mathrm{~g} / \mathrm{t}$.
\end{abstract}

Keywords: Pb-Zn complex ore, Ulukışla-Madenköy, grinding, flotation, Aerophine 3418A.

\section{INTRODUCTION}

Niğde-Ulukışla zinc-lead deposits are located within a $12 \mathrm{~km}$ long and $6 \mathrm{~km}$ wide area extending between Horoz Village and Maden Village. The beds are available in three forms as both sulphide and carbonaceous and carstic placer type [1]. Bolkardağ and its region is known to be very important in terms of economics and has been known for many years since gold and silver high-lead-zinc deposits are also known. These mineralizations are generally composed of sulphide minerals (pyrite, pyrrhotite, marcasite, galena, sphalerite, chalcopyrite) and are known to be of hydrothermal origin [2]. Flotation is a physicochemical enrichment method that allows the separation of hydrophobic minerals from hydrophilic grains by utilizing the surface-interface properties of the minerals within the ore [3,4]. Depending on the modified surface properties, the adhesion force between the air bubble and the mineral grain will increase or decrease. As the adhesion strength increases in hydrophobic minerals, adhesion strength will decrease in hydrophilic minerals. Therefore, hydrophobic and hydrophilic properties of minerals are of great importance in order to achieve flotation. Sulphur-containing minerals, oxide-structured minerals and non-metallic minerals are enriched by flotation method. There are three types of flotation process: foam, film and oil flotation. Foam flotation is the most commonly used method in the mining and metallurgy industry [3-6]. In most of the studies made in the recovery of sulphur minerals, xanthate type collectors, alcohol type foaming agents, as well as various inorganic and organic regulatory reagents are used [3,7-9]. Especially, $\mathrm{ZnSO}_{4}$ is used for depression of sphalerite in the flotation of $\mathrm{Pb}-\mathrm{Zn}-\mathrm{Cu}$ complex ores. It is known to be used in combination with zinc sulphate cyanide $[10,11]$. It is used in the suppression of pyrite, sphalerite and galena in the form of sodium sulfide, sodium bi-sulfide, sodium metabisulfite or sulphur dioxide [12-15]. In order to suppress silicates, sodium silicate is usually added. It is known that Aerophine 3418 is P-based sulphurous collector. It was originally developed for flotation of copper minerals and active zinc minerals. As a result, it is stated that flotation of galena and other precious metals (especially silver) is also highly effective [16]. In addition, 3418A collector was used with collector 208 coded collector in jewellery origin slag. It was determined to be effective in gold and silver recovery [17]. In this study, grinding + flotation experiments were performed on the sample of complex $\mathrm{Pb}-\mathrm{Zn}$ sulphide ore taken from Niğde (Ulukışla-Madenköy) region in Turkey. In the flotation studies, the effect of Aerophine 3418A collector dosage on flotation was investigated. In order to prevent the formation of critical micelle concentration, determining the 
optimum dosage amount of $3418 \mathrm{~A}$ is the main purpose of the study.

\section{MATERIAL AND METHODS}

\subsection{Preparation of ore sample}

In this study, sulphur-containing complex ore (SCO) from Niğde (Ulukışla-Madenköy) region was used. The ore sample for use in laboratory scale studies was taken from the stock area in the facility. Firstly, sample ore was passed through jaw crusher and reduced to below $25 \mathrm{~mm}$. Then, in the secondary crushing phase, the ore was crushed by a cone crusher to a size of $-6.3 \mathrm{~mm}$. The crushed ore was prepared in 1000 grams packs for use in grinding+flotation studies by homogenizing them by conic- quartering method.

\subsection{Chemical analysis of ore sample}

To determine the ore content, representative samples obtained after the conic crusher were milled in the ring grinding at a size of -75 microns. Approximately 2 grams of sample were dissolved in aqua regia (3 volumes of $\mathrm{HCl}+1$ volume of $\mathrm{HNO}_{3}$ ). $\mathrm{Ag}, \mathrm{Pb}, \mathrm{Zn}, \mathrm{Fe}, \mathrm{Cu}$ and $\mathrm{As}$ elements were analysed by Agilent brand AAS device. Fire-Assay method was applied for $\mathrm{Au}$ analysis. Element analysis results were given in Table 1.

Tablo 1. Elemental analysis values of the ore sample.

\begin{tabular}{|l|l|}
\hline Element & Content \\
\hline $\mathrm{Au}(\mathrm{ppm})$ & 2.58 \\
\hline $\mathrm{Ag}(\mathrm{ppm})$ & 187 \\
\hline $\mathrm{Zn}(\%)$ & 6.36 \\
\hline $\mathrm{Pb}(\%)$ & 3.20 \\
\hline $\mathrm{Fe} \mathrm{( \% )}$ & 14.69 \\
\hline $\mathrm{Cu}(\mathrm{ppm})$ & 230 \\
\hline $\mathrm{As}(\%)$ & 0.81 \\
\hline $\mathrm{S}(\%)$ & 18.60 \\
\hline
\end{tabular}

\subsection{Mineralogical analysis of ore sample}

According to the mineralogical analysis of this sample, the main minerals are sphalerite $(\mathrm{ZnS})$, galena $(\mathrm{PbS})$, chalcopyrite $\left(\mathrm{CuFeS}_{2}\right)$, arsenopyrite (FeAsS), pyrite $\left(\mathrm{FeS}_{2}\right)$, marcasite $\left(\mathrm{FeS}_{2}\right)$ and iron minerals (hematite $\left(\mathrm{Fe}_{2} \mathrm{O}_{3}\right)$, goethite $(\mathrm{FeOOH})$, limonite $\left(\mathrm{FeO}(\mathrm{OH}) . \mathrm{nH}_{2} \mathrm{O}\right)$. The gangues of the ore are composed of gypsum $\left(\mathrm{CaSO}_{4} \cdot 2 \mathrm{H}_{2} \mathrm{O}\right)$, quartz $\left(\mathrm{SiO}_{2}\right)$, calcite $\left(\mathrm{CaCO}_{3}\right)$ and clay type minerals. It has been determined that there are pyrite-marcasite, galena and sphalerite minerals in polished section (Fig. 1). However, the ore sample contains mainly natural gold, natural silver and electrum. Gold and silver are present in the form of inclusions in the iron and clay minerals.

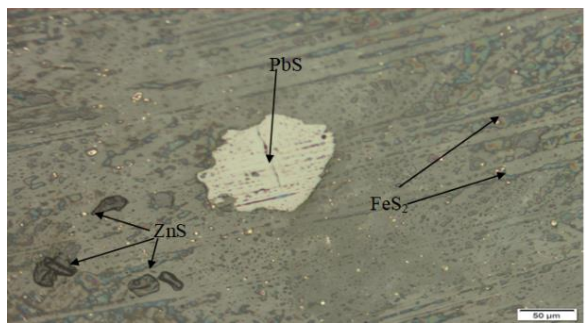

Figure 1. Slim and polished section view of the ore sample.

\subsection{Experimental procedure}

The ore was reduced a size of $6.3 \mathrm{~mm}$ after two crushing stages. It is packaged with homogeneity for use in grinding and flotation experiments. This ore sample was milled at a mill size $\varnothing 180 \times 362 \mathrm{~mm}$ with an internal volume of $9 \mathrm{~L}$. It was ground $\left(\mathrm{d}_{80}=75 \mu \mathrm{m}\right)$ and fed to the flotation cell (Fig. 2).

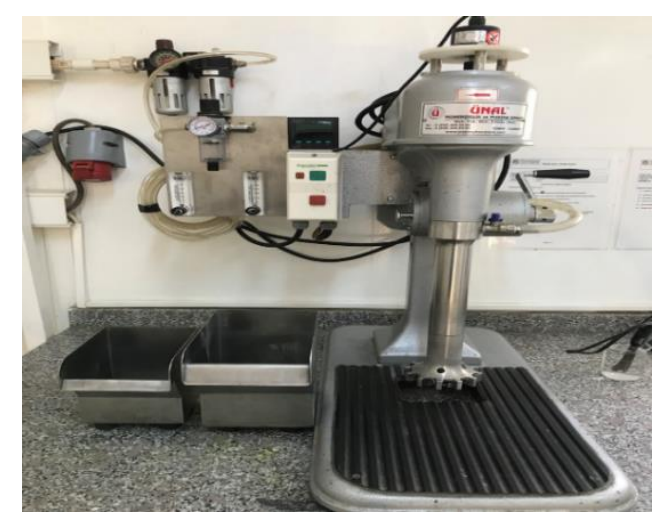

Figure 2. The flotation device used in the experiments.

Flotation experiments were carried out using a Denver type flotation device with a constant solid ratio of $30 \%$, a flow rate of $10 \mathrm{~L} / \mathrm{min}$, a stirring speed of $1250 \mathrm{rpm}$ and $\mathrm{pH}=9$. Lime ( $\mathrm{pH}$ adjuster), zinc sulphate, sodium silicate (quencher), sodium isobutyl dithiophosphine (collector) and methyl isobutyl carbinol (foaming agent) were used in flotation tests. The chemical structure of Aerophine 3418A (sodium isobutyl dithiophosphine) given in Figure 3 is known as the P-based sulphurous mineral collector produced by Cytech [18].

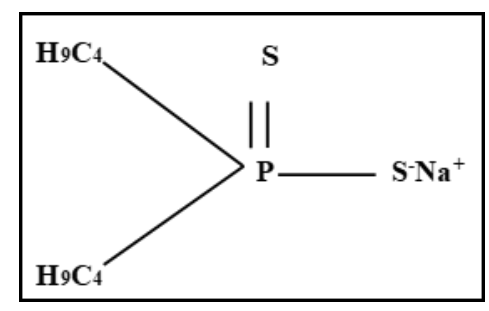

Figure 3. Chemical structure of Aerophine 3418A. 
It is stated that flotation of galena and other precious metals (especially silver) is highly effective in this collector [16]. It provides a great selectivity against pyrite, arsenopyrite and suppressed sphalerite minerals in complex ores. Because of this feature, it is known that Aerophine 3418A is used instead of xanthates in many plants [19].

\section{RESULTS AND DISCUSSION}

The effect of Aerophine 3418A (sodium isobutyl dithiophosphine) collector dosage was investigated in grinding + flotation studies. Test conditions are summarized in Table 2.

Table 2. Experimental conditions and reagents for grinding and flotation conditions.

\begin{tabular}{|l|c|c|c|c|c|}
\hline Stage & Time & \multicolumn{4}{|l|}{ Reagent quantities (g/t) } \\
\cline { 3 - 6 } & & $\mathrm{ZnSO}_{4}$ & $\mathrm{Na}_{2} \mathrm{SiO}_{3}$ & $\begin{array}{l}\text { Aerophine } \\
3418 \mathrm{~A}\end{array}$ & $\mathrm{MIBC}$ \\
\hline Grinding & 8 & 1000 & 500 & & \\
\hline Elotation & & & & & \\
\hline Conditioning I & 3 & 1000 & 500 & $\begin{array}{c}5,10,15, \\
20\end{array}$ & \\
\hline Conditioning 2 & 2 & & & & 20 \\
\hline Conditioning 3 & 1 & & & & \\
\hline Eocunjigg & 4 & & & & \\
\hline
\end{tabular}

According to the best results obtained by Y1lmaz, 2019 [20] constant conditions were determined. Experiments were carried out using these conditions given in Table 2 . The test results were given in Table 3. According to Table 3, the amount of $\mathrm{Ag}$ and $\mathrm{Pb}$ in the concentrate appears to be very high. $\mathrm{Ag}$ and $\mathrm{Pb}$ values and recoveries of the concentrate were shown in Fig. 4.

As can be seen from Table 3, it was observed that the contents of $\mathrm{Ag}$ and $\mathrm{Pb}$ in the concentrate increase. The reason for this is the increased selectivity of both sphalerite and pyrite [21]. Ceylan and Bulut, (2016) [19] performed flotation experiments on a representative copper sample from Siirt-Madenköy. It was determined that the most suitable collector for the purpose was Aerophine 3418A with the amount of $50 \mathrm{~g} / \mathrm{t}$. In a different study, chalcopyrite, galena and sphalerite were selectively recovered in three rougher flotation cells using the Aero 3894 and 3418A collectors [22].

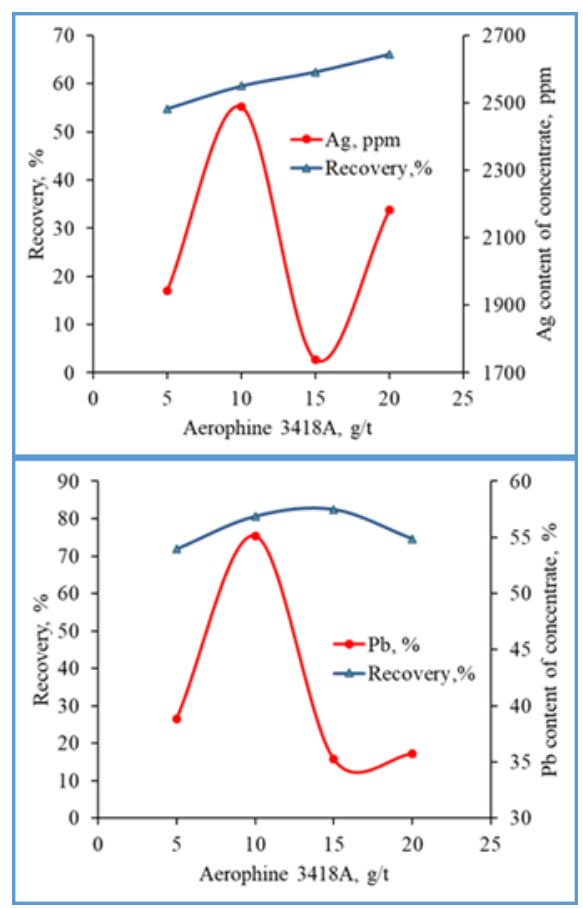

Figure 4. $\mathrm{Ag}$ and $\mathrm{Pb}$ content and recoveries of concentrate depending on the amount of Aerophine 3418A.

Table 3. Results of experiments with Aerophine 3418

\begin{tabular}{|c|c|c|c|c|c|c|c|c|c|c|c|c|c|c|}
\hline \multirow{2}{*}{$\begin{array}{l}\text { Amount } \\
\text { of } \\
\text { collector } \\
(\mathrm{g} / \mathrm{t})\end{array}$} & \multirow[b]{2}{*}{ Products } & \multirow{2}{*}{$\begin{array}{l}\text { Amount } \\
(\%)\end{array}$} & \multicolumn{2}{|c|}{$\mathrm{Au}$} & \multicolumn{2}{|c|}{$\mathrm{Ag}$} & \multicolumn{2}{|c|}{$\mathrm{Zn}$} & \multicolumn{2}{|c|}{$\mathrm{Pb}$} & \multicolumn{2}{|c|}{$\mathrm{Fe}$} & \multicolumn{2}{|c|}{$\mathrm{Cu}$} \\
\hline & & & $\begin{array}{c}\text { Content } \\
\text { (ppm) }\end{array}$ & $\begin{array}{l}\text { Rec. } \\
(\%)\end{array}$ & $\begin{array}{c}\text { Content } \\
\text { (ppm) }\end{array}$ & $\begin{array}{l}\text { Rec. } \\
(\%)\end{array}$ & $\begin{array}{c}\text { Content } \\
(\%)\end{array}$ & $\begin{array}{l}\text { Rec. } \\
(\%)\end{array}$ & $\begin{array}{c}\text { Content } \\
(\%)\end{array}$ & $\begin{array}{l}\text { Rec. } \\
(\%)\end{array}$ & $\begin{array}{c}\text { Content } \\
(\%)\end{array}$ & $\begin{array}{l}\text { Rec. } \\
(\%)\end{array}$ & $\begin{array}{c}\text { Content } \\
\text { (ppm) }\end{array}$ & $\begin{array}{l}\text { Rec. } \\
(\%)\end{array}$ \\
\hline \multirow{3}{*}{5} & Concentrate & 6.34 & 3.78 & 11.99 & 1943 & 54.81 & 4.97 & 5.17 & 38.85 & 71.87 & 6.31 & 3.12 & 442 & 9.91 \\
\hline & Tailing & 93.66 & 1.88 & 88.01 & 109 & 45.19 & 6.18 & 94.83 & 1.03 & 28.13 & 13.29 & 96.88 & 272 & 90.09 \\
\hline & Feed & 100 & 2.00 & 100 & 225 & 100 & 6.10 & 100 & 3.43 & 100 & 12.85 & 100 & 283 & 100 \\
\hline \multirow{3}{*}{10} & Concentrate & 5.29 & 4.79 & 11.70 & 2489 & 59.52 & 5.29 & 4.70 & 55.13 & 80.63 & 7.3 & 3.10 & 426 & 8.89 \\
\hline & Tailing & 94.71 & 2.02 & 88.30 & 95 & 40.48 & 5.99 & 95.30 & 0.74 & 19.37 & 12.73 & 96.90 & 244 & 91.11 \\
\hline & Feed & 100 & 2.17 & 100 & 221 & 100 & 5.95 & 100 & 3.62 & 100 & 12.44 & 100 & 254 & 100 \\
\hline \multirow{3}{*}{15} & Concentrate & 8.20 & 3.56 & 13.43 & 1739 & 62.40 & 5.23 & 7.58 & 35.25 & 82.46 & 9.66 & 6.43 & 400 & 12.08 \\
\hline & Tailing & 91.80 & 2.05 & 86.57 & 94 & 37.60 & 5.70 & 92.42 & 0.67 & 17.54 & 12.55 & 93.57 & 260 & 87.92 \\
\hline & Feed & 100 & 2.17 & 100 & 229 & 100 & 5.66 & 100 & 3.51 & 100 & 12.31 & 100 & 271 & 100 \\
\hline \multirow{3}{*}{20} & Concentrate & 7.47 & 3.29 & 11.47 & 2182 & 66.13 & 4.62 & 6.12 & 35.72 & 74.63 & 8.11 & 5.07 & 352 & 9.85 \\
\hline & Tailing & 92.53 & 2.05 & 88.53 & 90 & 33.87 & 5.72 & 93.88 & 0.98 & 25.37 & 12.25 & 94.93 & 260 & 90.15 \\
\hline & Feed & 100 & 2.14 & 100 & 246 & 100 & 5.64 & 100 & 3.57 & 100 & 11.94 & 100 & 267 & 100 \\
\hline
\end{tabular}

As a result of studies carried out by Zhong et al. (2015) [23], Aerophine 3418A was demonstrated more efficient aggregation ability and better selectivity for copper sulfide and lead-zinc sulphide ores. As shown in Fig. 4, as a result of single-stage flotation experiments, $\mathrm{Ag}$ content of concentrate was obtained as 2489 ppm with a recovery of 
$60 \%$ and $\mathrm{Pb}$ content of concentrate was obtained as $55.13 \%$ with recovery of $80.63 \%$. According to these results, the amount of Aerophine 3418A collector was determined as 10 g/t. Acarkan et al. (2011) [16] stated in their study that Aerophine 3418A and Aero 208 combination was more effective than oxidized lead minerals in flotation of $\mathrm{Au}$ and Ag. Using this combination, they performed 7-stage flotation experiments and obtained a concentrate containing $920 \mathrm{ppm}$ $\mathrm{Au}, 10100 \mathrm{ppm} \mathrm{Ag}$ and $11.38 \% \mathrm{~Pb}$. In another study using Aerophine 3418A and Aero 208 combination, it was stated that $85.9 \% \mathrm{Au}$ and $91.6 \% \mathrm{Ag}$ recoveries were reached and using the same amount of ATP + KAX combination, a concentrate with higher content of $\mathrm{Au}$ and $\mathrm{Ag}$ was obtained with lower recoveries [24].

The following flow diagram has been proposed for further studies (Fig. 5).

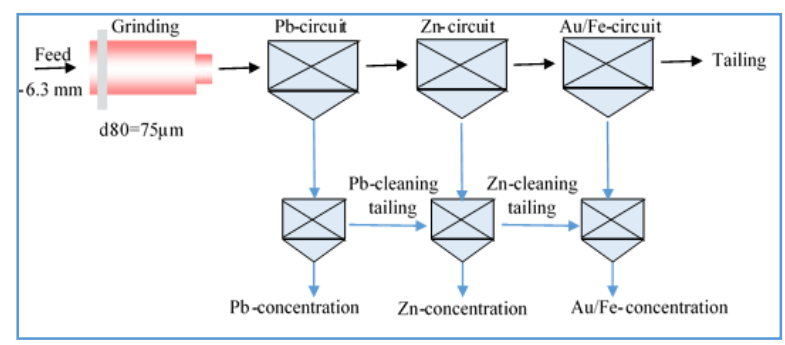

Figure 5. Recommended flow diagram for further stages.

\section{CONCLUSIONS}

In this study, the samples were obtained from Niğde (Ulukışla-Madenköy) region. As a result of chemical and mineralogical investigations, the ore was found to have $\mathrm{Pb}$ $\mathrm{Zn}$ complex form with sulfur content. It was determined that the ore contains calcite, quartz, pyrite, chalcopyrite, hematite, goethite, limonite, gypsum, galena, sphalerite, arsenopyrite, marcasite and clay type minerals. The ore used in the experiments was found as $3.20 \% \mathrm{~Pb}, 6.36 \% \mathrm{Zn}, 14.69$ $\% \mathrm{Fe}, 0.81 \% \mathrm{As}, 16.60 \% \mathrm{~S}, 2.58 \mathrm{ppm} \mathrm{Au}, 187 \mathrm{ppm} \mathrm{Ag}$ and $230 \mathrm{ppm} \mathrm{Cu}$. Grinding and flotation experiments were performed using different reagents for this ore. In flotation studies, the effect of different amounts of Aerophine 3418A on the experimental results was investigated. As a result, a concentrate of $55.13 \% \mathrm{~Pb}$ was obtained and it was found that this concentrate contained $2489 \mathrm{ppm}$ of Ag. The amount of Aerophine 3418A collector was determined as $10 \mathrm{~g} / \mathrm{t}$. Zinc, iron, copper minerals and gold remained in the tailing. In particular, the zinc flotation circuit and pyrite flotation cleaning cycle can be used to obtain gold and zinc in the tailing. It may be advisable to use copper sulfate to float the zinc contained in the tailing. In particular, to obtain gold concentrate, xantates, Aerophine 3418A, F2216 and their blends may be preferred as collectors.

\section{Acknowledgements}

The authors would like to thank Konya Technical University and the reviewers because of their contributions.

\section{REFERENCES}

[1] S. Temur, "Bolkardağı yöresi (Ulukışla/Niğde) çinkokurşun yataklarının jeokimyasal incelemesi”. Türkiye Jeoloji Bülteni, Sayı: 35, s: 101-114, 1990.

[2] N. Şişman, M.H. Şenocak, S. Dilek, M. Yazgaç, "Bolkardağ yöresinin jeolojisi ve maden yatakları", MTA Genel Müdürlüğü, Rapor No: 7202, Ankara, (1981).

[3] S. Atak, Flotasyon ilkeleri ve uygulaması, İstanbul, 1990.

[4] A. M. Gaudin, Flotation, McGraw Hill, New York, 1957. [5] J. S. Laskowski, Frothing in Flotation II, G\&B Science, 1998.

[6] B.K. Parekh, J. D. Miller, Advances in flotation technology, Soc. for Mining Metallurgy, New York, 1999.

[7] L. Leja, Surface Chemistry of Froth Flotation. New York, 1982.

[8] N. Arbiter, SME Mineral Processing Handbook, Volume I, New York, 1985.

[9] B.A. Wills, Mineral Processing Technology. Fourth Edition, 1988.

[10] M. Cao, Q. Liu, "Re-examining the functions of zinc sulphate as a selective depressant in differential sulphide flotation the role of coagulation", Journal of Colloid and Interface Science, vol. 301, pp. 523- 531, 2006.

[11] S.M. Bulatovic, Handbook of flotation reagents, chemistry. theory and practice, flotation of sulfide ores, Elsevier, Amsterdam, 2007.

[12] S.R. Grano, M. Sollaart, W. Skinner, C.A. Prestidge, J. Ralston, "Surface modifications in the chalcopyrite-sulphite ion system. I. collectorless flotation, XPS and dissolution study" International Journal of Mineral Processing, vol. 50(2), pp. 1-26, 1997.

[13] S.R. Grano, N.W. Johnson, J. Ralston, "Control of the solution interaction of meta bisulphite and ethyl xanthate in the flotation of the Hilton ore of Mount Isa Mines Limited, Australia", Miner. Eng., vol. 10 (1), pp. 17, 1997a.

[14] S.R. Grano, C.A. Prestidge, J. Ralston, "Solution interaction of ethyl xanthate and sulphite and its effect on galena flotation and xanthate adsorption", Int. J. of Miner. Process. Vol. 52, pp. 161-186, 1997b.

[15] T.N. Khmeleva, J.K. Chapelet, W.M. Skinner, D.A. Beattie, "Depression mechanisms of sodium bisulphite in the xanthate-induced flotation of copper activated sphalerite", International Journal of Mineral Processing. Vol.79, pp. 61-75, 2006.

[16] N. Acarkan, G. Bulut, A. Gül, O. Kangal, F. Karakaş, O. Kökkılıç, G. Önal, "The effect of collector's type on gold and silver flotation in a complex ore", Sep. Sci. Technol. Vol. 46, pp. 283-289, 2011.

[17] C. Durmaz, "Kuyumculuk kökenli curüflardan fiziksel zenginleştirme yöntemleri ile altının geri kazanımı”, Yüksek Lisans Tezi, İstanbul, 2012.

[18] Cytec Mining Chemical Handbook, 2002.

[19] A. Ceylan, B. Bulut, "Siirt-Madenköy bakır cevherinin flotasyon yöntemiyle zenginleştirilmesi", Madencilik, sayı. 55 (1), s. 17-26, 2016.

[20] B. B. Yilmaz, “ Niğde (Ulukışla-Madenköy) Bolkardağı sülfürlü kurşun-çinko kompleks cevherinin optimum 
flotasyon şartlarının belirlenmesi”, Yüksek Lisans Tezi, Konya, 2019.

[21] P. Mingione, "Use of AEROPHINE® 3418A promoter for sulphide minerals flotation" in The 120th Annual Meeting of SME/AIME and 75th Annual Meeting of WAAIME, Feb. 25-28, Denver, Colorado, p.54 1991.

[22] D.M. Veneu, T.F.M. Brasil, G.G. DeOliveira Junior, W. Phillips, R.B. Gomides, C. L. Schneider, M.B. DeMello Monte, "Recovery of sulphides as by products from a gold flotation circuit", in 67th abm International Congrees, pp.
1211-1220, 2012.

[23] H. Zhong, Z. Huang, G. Zhao, S. Wang, G. Liu, Z. Cao, "The collecting performance and interaction mechanism of sodium diisobutyl dithiophosphinate in sulfide minerals flotation", J. Mater. Res. Technol. Vol. 4(2), pp. 151-161, 2015.

[24] Ş. B. Aydın, D. Aydın, A. Gül, "Refrakter Olmayan Sülfürlü Altin-Gümüş Cevherinin Flotasyon Davranişinin İncelenmesi” NOHU J. Eng. Sci., Vol. 9(2), pp. 1039-1053, 2020 . 